\title{
The Relations between Investment in Employees' Development and Organizational Productivity and Service Quality
}

\author{
Ivana KATIĆ, Nemanja BERBER, Agneš SLAVIĆ, Andrea IVANIŠEVIĆ
}

\begin{abstract}
Human resource management (HRM) is directed to managing human potentials of a company in order to achieve organizational goals, and at the same time, goals of employees. One of the very important part of this process is training and development, as a group of activities aimed at improving employees knowledge, skills, and abilities (KSA), in order to be more successful in job, but also with the aim of creating a base for further development of an organization as a whole. The main aim of the research was to explore the effects of investment in employees' development, measured by number of training days and percentage of operating costs invested in development and training, on the level of organizational productivity and service quality. The subject of the research is the relationship between two main indicators of employees' development program, and organizational level productivity and service quality. The methodology used in the research obtained the application of two-way multivariate analysis of variance (MANOVA) on the data from 160 companies from one Southeast European country, gathered during 2015 and 2016 . The results indicated that there is an interaction effect between training costs and number of training days on the combined dependent variables, productivity and service quality in the observed organizations.
\end{abstract}

Keywords: Human resource management; organizational performances; Serbia; training and development

\section{INTRODUCTION}

Modern business is characterised by several important trends, globalization, political and economic instability, environmental issues and demands, digitalization, etc. All those trends influence changes in the area of work, where the most sensitive subjects are people, employees. New challenges lead to the changes in almost all areas of workfrom the basic skills and knowledge that are necessary for the successful completion of the job, organization of working process, nature of job design, model for rewarding, performance management, employees' engagement, etc.

In the new economy that is based on innovations and knowledge employees need to be familiar with the latest technologies in all areas-industry, service, agriculture, information technology (IT) sector. The way that modern companies can enlarge their knowledge base is to invest in their employees, as human potentials that are inevitably one of the key factors to sustain long-term competitiveness of the organizations $[1,2]$. Human resource management (HRM) is the process through which management builds the workforce and tries to create human performances that the organisation needs [3]. It consists of several activities such as job design and job analysis, personnel planning, recruitment and selection, orientation and socialization, performance management, rewarding, training and development, employee relations, retirement, etc. [4]. Training and development takes special place among HRM activities since it is directly related to the increase and enhancement of employees' knowledge, skills and abilities (KSA) [5-7] which are found to be positively related to the organizational outcomes [8-11].

The main aim of the research was to explore the effects of investment in employees' development, measured by number of training days and a percentage of operating costs invested in development and training, on the level of organizational productivity and service quality. The subject of the research is the relationship between two main indicators of employees' development program, and organizational level productivity and service quality. The methodology used in the research obtained the application of two-way multivariate analysis of variance (MANOVA).

The paper consists of three parts. In the first part the authors presented the most important literature sources based on past research between observed variables. In the second part the authors presented the methodology and results of the study, where they used two-way MANOVA test. The last part of the paper is dedicated to the discussion, conclusion and possible limitations of the study.

\section{THEORETICAL BACKGROUND}

Training is defined as a learning process that involves acquiring skills, adopting rules, and forming attitudes. Training of employees, seen as human capital investment, can have positive economic value because it develops the knowledge and skills of employees, thereby improving their productivity [12]. Effective training takes place when learners are consciously provided with pedagogical abilities to learn the necessary knowledge, skills and attitudes (KSAs) through instruction, demonstration, practice, and timely diagnostic feedback on their work [13]. It is assumed that the quality of initial training can be crucial for the productivity and attitude of workers towards work [14]. It is found that training programmes and individual development plans have special importance in attracting and retaining talented employees [15], and in creating healthy and sustainable organizations [16, 17].

As jobs become more global, competition puts the need for a more capable workforce. When the education system at the state level does not provide the necessary education for employees then the burden of education falls on employers. According to the CRANET network research, average costs invested in training and employee development are estimated at around $3-4 \%$ of the total wage costs for employees in European countries [10, 19].

Companies that provide broad-based training for their employees actually "treat" their training programs as an "investment" for the future [18] rather than just as a "cost" that needs to be reduced, i.e. employees training must be 
understood as the development of "assets" and not as an expense that has to be reduced [12]. Also, the role of training has changed so today it is viewed not only as "a way to enhance individual capabilities but also as a valuable lever for improving team effectiveness and for organizations to gain competitive advantage" [20-22].

According to Russian authors, it is also very important to bear in mind that often research in the area of employees' training focuses on the search for effective methods of functioning and development of guidance for companies to organize training. "Approaches to assessing the impact of learning generally rely on the assessment of the degree of achievement of goals and use simplified performance evaluation of teaching, which, however, are quite intuitive and easy to use, although they do not always allow to obtain the accurate and correct assessment of the economic result" [23].

What is very often related to training of employees is the question of how it influences the changes in organizational performances. In the continuation of the text this relationship will be explored to a greater extent.

\subsection{Relationship Between Training, Productivity and Service Quality}

Many researches in the past have been conducted with the aim of proving the positive and significant relationship between training and development activities and organizational performances [21-27]. It is confirmed that training programs can help employees in achieving better knowledge, skills and abilities, and, on that basis, higher performances. Also, as a result of investment in training of employees, companies can reach higher level of organizational performances. Employees' training enables successful service quality implementations. Training brings employees the ability to deliver quality services to customers and it enables them to quickly respond to the ever-changing needs of customers [28].

In their research, Saravani and Abbasiin 2013 found that job rotation system causes enhancing productivity of employees and improves organizational performance in both organization and individual. Also, they found that the greatest advantage for employees is increased job satisfaction, beside higher productivity [25]. Similarly, Cvjetković et al. investigated the importance of training of employees regarding the implementation of quality standards in a company. They proved that the implementation of the standards does not enable the improvement of the business performances and does not bring significant effects without simultaneously provided training of the employees. In this research the authors proved that employees' training is crucial in achieving higher level of organizational performances [27].

Van Iddekinge et al. examined the impact of selection and training on customer service and financial performance in 861 fast-food restaurants. They found that the use of training is both directly related to financial performance and indirectly to improved customer service [29].

Morley et al. claim that a developed training practice positively influences organizational performances (which were expressed by service quality, productivity, profitability and rate of innovations in their research). These authors explored the role of the training practice in improving organizational performances in eight Central and Eastern European countries, on the sample of 1147 organizations. They found that the internationalization of the market on which organizations operate, had significantly positive influences on the companies' training practice in the CEE region, which in turn gained better service quality, productivity, profitability, and rate of innovation [10].

Dhar investigated the relationship between perceived accessibility to training, support for training, benefits from training, and the implications of training on service quality mediated through organizational commitment on the sample of 494 employees in a hotel in India. The findings showed strong positive relationship between employees' training and the quality of services in tourist hotels [30]. KyoonYoo and Ah Park made an analysis based on a sample of 129 hotels in Korea, proposing that the employees' training has a positive influence on perceived service quality. They proved their hypothesis, and found that organizations that have a high level of employees' training have a high level of perceived service quality [28].

In case of restaurants, Arroyo-López et al. showed that the training of service of employees contributes to enhancing the customer's service experience in the context of small, family-owned provincial restaurants. According to them, training becomes relevant to develop proper service skills and customer orientation [31].

Aragón-Sánchez et al. investigated the relation between training and business success in small and medium size organizations (SME) in Europe, based on 457 SMEs. They found that, although HRM and training practices are less developed in SMEs, a positive influence of training activities on business results was detectedeffectiveness (employees' involvement, human resource indicators, and quality) and profitability [32].

Zumrah investigated the relationships among perceived organizational support, transfer of training outcomes to the workplace and service quality in the context of public sector organizations in Malaysia. The author found that transfer of training had a mediating effect on the positive relationship between perceived organizational support and service quality [33].

Based on the above mentioned it can be concluded that there is strong connection between training of employees and performances. The authors proposed their research hypothesis:

H1: Companies that invest more in training of employees (measured by a percentage of annual labour costs spent on training and a number of days spent on training) have higher level of business performances (productivity and service quality in organizations).

\section{METHODOLOGY}

The research in this paper is based on Cranet methodology and its questionnaire. Cranet is a network of scientific institutions from various countries that collect unique and interconnected comparable data on human resources policy and practice. This network is established in 1989, and it carried out the largest research on human resources management in practice around the world, and has a current picture of the state of practice in member countries. Coordination of activities is carried out by the 
Centre of European HRM at Cranfield School of Management in the UK [10]. Currently, the organization has about 40 members, not only from Europe. Members of the network are Japan, Canada, India, USA, etc.

In 2015 and 2016 the authors examined 160 organizations in Serbia. Answers to questions were given by Human Resources Managers or Executive Managers in organizations with more than 50 employees [34].

The survey is using a standardized questionnaire, which is translated into the languages of the participating countries. The research is of descriptive character and relies on objective data and contains mostly closed questions. The survey questionnaire has about 70 questions and covers the main HRM activities. Structure of the questionnaire is as follows:

- The first part deals with the characteristics of HR departments of analysed organizations.

- The second part of the questionnaire puts emphasis on the staffing practice of the organizations surveyed.

- The third part deals with the issues of employee training and development.

- The fourth part deals with the management of the performance of employees, the way of determining the basic salary, incentive earnings and benefits provided to employees.

- The fifth part of the questionnaire analyses the relationship between employers and employees and deals with various issues of communication with employees.

- The sixth section contains basic organizational data.

- The seventh part refers to the data of the persons who completed the questionnaire.

\subsection{Sample}

The authors gathered responses from HR or executive managers from 160 organizations. The largest share of the sample was the SME sector, $60 \%$. There are $27 \%$ of large organisations and $13 \%$ of very large, with more than 1000 employees. The sample also consisted mainly of organisations from private $(66 \%)$ sector. About $37 \%$ of analysed organisations were from production sector, and $63 \%$ of organisations from the service sector. The majority of analysed organisations were from food production, trade, telecommunication, and IT business.

\subsection{Variables}

For the purpose of this paper the authors used two independent variables, based on [19] training indicators: training costs which represent the ratio of the annual training budget in the total payroll costs, and annual training days provided for employees. Training costs were divided in three groups (group 1 from 0 to $2 \%$, group 2 from 2 to $5 \%$, and group 3, more than 5\%). Variable "An average number of days spent on training" was created in two steps. In the first step the authors made an average number of days spent on training based on days for training of three different groups of employees - managers, professional and manual workers. In the second step there was a new variable, divided in three groups where the first group consisted of organizations that invested from 0 to 5 days for training, the second group was made from organizations that invested from 5 to 10 days, and in the third group there were organizations that invested more than 10 days annually in their employees' training.

The authors used two dependent variables, the level of productivity and the level of service quality. Both variables were measured through questions "How would you rate the level of organizational productivity/service quality". The range of the Likert scale was from 1 (poor) to 5 (superior). This estimation was given by managers who filled in the questionnaire. Both measures are very important for each company. It is necessary to systematically approach quality, since customers want the highest possible quality at the lowest possible price [35]. In relation to the first, productivity can be achieved and maintained only by adopting modern approaches like just in time philosophy [36].

\subsection{Methods}

The analysis of the data was processed by SPSS software version 21. The authors used Spearman's Correlation and two-way MANOVA to explore the relations between dependent and independent variables. The correlation was performed to explore the relations between observed variables, and two-way MANOVA was performed to explore statistically significant interaction effect between training costs and number of training days on the combined dependent variables.

\section{RESULTS AND DISCUSSION}

The data in tables below show main results of computed two-way MANOVA. Before MANOVA, the authors ran several tests to ensure that the MANOVA can be used for the analysis. According to the data in Tab. 1 and 2, there is no homogeneity of covariance matrices and Levene's tests showed that variances of each variable are equal across the groups. Based on these tests the authors decided to apply two-way MANOVA in order to explore proposed relations between variables.

Table 1 Box's test of equality of covariance matrices

\begin{tabular}{|c|c|}
\hline Box's M & 17,543 \\
\hline$F$ & 0,790 \\
\hline $\mathrm{d} f_{1}$ & 21 \\
\hline $\mathrm{d} f_{2}$ & 24866,767 \\
\hline Sig. & 0,736 \\
\hline
\end{tabular}

Table 2 Levene's test of equality of error variances

\begin{tabular}{|l|c|c|c|c|}
\hline & $F$ & $\mathrm{~d} f_{1}$ & $\mathrm{~d} f_{2}$ & Sig. \\
\hline Productivity & 0,816 & 8 & 147 & $\mathbf{0 , 5 8 9}$ \\
\hline Service quality & 1,151 & 8 & 147 & $\mathbf{0 , 3 3 3}$ \\
\hline
\end{tabular}

The data in Tab. 3 show results of computed Spearman's rho correlation. There are statistically significant correlations between dependent and independent variables. The level of training costs, as percentage of annual labor costs invested in training, is positively correlated with the level of productivity ( $r h o=$ $0,217 ; p<0,01)$ and service quality $(r h o=0,247 ; p<0,01)$. A number of training days spent on training, as second important training determinant, is positively correlated to the productivity $(r h o=0,195 ; p<0,05)$ and level of service quality $(r h o=0,229 ; p<0,01)$. Also, productivity and 
service quality are positively correlated (rho $=0,680 ; p<$ $0,01)$.

Table 3 Means, standard deviations and correlations of variables

\begin{tabular}{|l|c|c|c|c|c|c|}
\hline & Mean & $S D$ & $T C$ & TD & Prod & Servq \\
\hline TC & 2,01 & 0,87 & 1,000 & & & \\
\hline TD & 1,69 & 0,75 & $0,195^{*}$ & 1,000 & & \\
\hline Prod & 3,58 & 0,84 & $0,217^{* *}$ & $0,195^{*}$ & 1,000 & \\
\hline Servq & 3,86 & 0,81 & $0,247^{* *}$ & $0,229^{* *}$ & $0,680^{* *}$ & 1,000 \\
\hline *. Correlation is significant at the 0,05 level (2-tailed). \\
\hline
\end{tabular}

The Multivariate tests in Tab. 5 show the actual result of the one-way MANOVA. According to the data form Wilks' Lambda row, there is significant effect of training costs on productivity and service quality $(F(4,292)=$ 3,392, $p=0,010$; Wilks' Lambda $=0,913$ ), while training days did not show statistically significant effect $(p>0,05)$. The most important results from the two-way MANOVA tests showed that there was a statistically significant interaction effect between training costs and number of training days on the combined dependent variables, $\mathrm{F}(8,292)=2,537, \mathrm{p}=0,011 ;$ Wilks' Lambda $=0,874$, Partial eta squared $=0,028$.

Table 4 Comparison between groups and variables

\begin{tabular}{|l|c|c|c|}
\hline \multicolumn{2}{|c|}{ TC } & Mean & SD \\
\hline Rating of level of \\
productivity & 1,00 & 3,38 & 0,768 \\
\cline { 2 - 4 } & 2,00 & 3,54 & 0,884 \\
\cline { 2 - 4 } & 3,00 & 3,83 & 0,813 \\
\cline { 2 - 4 } & Total & 3,59 & 0,834 \\
\hline Rating of service quality & 1,00 & 3,66 & 0,807 \\
\cline { 2 - 4 } & 2,00 & 3,83 & 0,747 \\
\cline { 2 - 4 } & 3,00 & 4,12 & 0,768 \\
\cline { 2 - 4 } & Total & 3,87 & 0,798 \\
\hline \multirow{3}{*}{$\begin{array}{l}\text { Rating of level of } \\
\text { productivity }\end{array}$} & 1,00 & 3,39 & SD \\
\cline { 2 - 4 } & 2,00 & 3,80 & 0,814 \\
\cline { 2 - 4 } & 3,00 & 3,69 & 0,737 \\
\cline { 2 - 4 } & Total & 3,58 & 0,841 \\
\hline Rating of service quality & 1,00 & 3,67 & 0,767 \\
\cline { 2 - 4 } & 2,00 & 4,06 & 0,738 \\
\cline { 2 - 4 } & 3,00 & 4,04 & 0,958 \\
\cline { 2 - 4 } & Total & 3,86 & 0,810 \\
\hline
\end{tabular}

Table 5 Multivariate test

\begin{tabular}{|c|c|c|c|c|c|c|c|c|}
\hline \multicolumn{2}{|r|}{ Effect } & Value & $F$ & Hynothesis $d f$ & Frror $d f$ & Sir & Portia Eta Sarared & Ohcerved Power \\
\hline \multirow{4}{*}{ Intercept } & Pillai's Trace & 0,953 & 1487,151 & 2,000 & 146,00 & 0,000 & 0,953 & 1,000 \\
\hline & Wilks' Lambda & 0,047 & 1487,151 & 2,000 & 146,00 & 0,000 & 0,953 & 1,000 \\
\hline & Hotelling's Trace & 20,372 & 1487,151 & 2,000 & 146,00 & 0,000 & 0,953 & 1,000 \\
\hline & Roy's Largest Root & 20,372 & 1487,151 & 2,000 & 146,00 & ,0000 & 0,953 & 1,000 \\
\hline \multirow[t]{4}{*}{$\mathrm{TC}$} & Pillai's Trace & 0,087 & 3,345 & 4,000 & 294,00 & 0,011 & 0,044 & 0,842 \\
\hline & Wilks' Lambda & 0,913 & 3,392 & 4,000 & 292,00 & 0,010 & 0,044 & 0,848 \\
\hline & Hotelling's Trace & 0,095 & 3,438 & 4,000 & 290,00 & 0,009 & 0,045 & 0,853 \\
\hline & Roy's Largest Root & 0,092 & $6,766^{\mathrm{c}}$ & 2,000 & 147,00 & 0,002 & 0,084 & 0,914 \\
\hline \multirow[t]{4}{*}{ TD } & Pillai's Trace & 0,056 & 2,114 & 4,000 & 294,00 & 0,079 & 0,028 & 0,624 \\
\hline & Wilks' Lambda & 0,944 & $2,131^{b}$ & 4,000 & 292,00 & $\mathbf{0 , 0 7 7}$ & 0,028 & 0,628 \\
\hline & Hotelling's Trace & 0,059 & 2,147 & 4,000 & 290,00 & 0,075 & 0,029 & 0,632 \\
\hline & Roy's Largest Root & 0,059 & $4,352^{\mathrm{c}}$ & 2,000 & 147,00 & 0,015 & 0,056 & 0,747 \\
\hline \multirow[t]{4}{*}{$\mathrm{TC} \times \mathrm{TD}$} & Pillai's Trace & 0,127 & 2,499 & 8,000 & 294,00 & 0,012 & 0,064 & 0,907 \\
\hline & Wilks' Lambda & $\mathbf{0 , 8 7 4}$ & $2,537^{b}$ & 8,000 & 292,00 & 0,011 & 0,065 & 0,912 \\
\hline & Hotelling's Trace & 0,142 & 2,575 & 8,000 & 290,00 & 0,010 & 0,066 & 0,916 \\
\hline & Roy's Largest Root & 0,128 & $4,705^{\mathrm{c}}$ & 4,000 & 147,00 & 0,001 & 0,114 & 0,946 \\
\hline \multicolumn{9}{|c|}{${ }^{\mathrm{a}}$ Design: Intercept $+\mathrm{TD}+\mathrm{TC}+\mathrm{TD} \times \mathrm{TC}$} \\
\hline \multicolumn{9}{|c|}{${ }^{\mathrm{b}}$ Exact statistic } \\
\hline
\end{tabular}

When the results of the dependent variables were investigated separately, it was concluded that in both cases, for both dependent, both independent variables and their interaction showed statistically significant effects.

According to the data in Tab. 6, there are statistically significant differences in the level of productivity and service quality in organization that invest different amount of money $\left(\mathrm{TC}, F_{\text {prod }}(2,147)=5,763 ; p=0,004 ; F_{\text {service }}\right.$ $(2,147)=5,304 ; p=0,006)$ and provide different number of days for training (TD, $\left.F_{\text {prod }}(2,147)=3,774 ; p=0,025\right)$.

In case of the effects of TD on service quality, since the $p$ value was adjusted based on Bonferroni rule, there was not detected statistically significant effect. Also, results of the test from Tab. 5 showed that the interaction between TC and TD variables had significant effect on both dependent variables $\left(\mathrm{TC} \times \mathrm{TD}, F_{\text {prod }}(4,147)=4,581\right.$; $\left.p=0,002 ; F_{\text {service }}(4,147)=2,883 ; p=0,025\right)$.

Post hoc tests from Tab. 7 revealed that there are statistically significant differences among companies that invest a certain amount of money in training regarding productivity and service quality. Companies that invest more than 5\% (third group) of their labour costs in training at annual level will have higher level of productivity $(M=$ 3,83 ) compared with companies that invest less than $2 \%$ (first group) $(M=3,38)$. There was no statistically significant difference between the second and other groups $(p=0,207$ and 0,965$)$.

A post hoc test also revealed that the service quality was statistically significantly lower if organizations invested less than $2 \%$ of the labour budget $(M=3,66)$ compared to the companies that invested more than 5\% (M $=4,12$ ). There was no statistically significant difference between the second and other groups ( $p=0,172$ and 0,873 ).

When comparing groups of companies that spent several number of days for training of their employees, a post hoc test (Tab. 7) showed that companies that invest less than 5 days for training (first group) will have lower level of productivity $(M=3,39)$ compared with companies that invest from 5 to 10 days (second group) $(M=3,80)$. There was no statistically significant difference between the third and other groups ( $p=0,322$ and 0,999$)$. Results from post hoc test in Tab. 7 also revealed that the service quality was statistically significantly lower if organizations spent less than 5 days $(M=3,67)$ compared to the companies that spent 5 to 10 days for training $(M=$ $4,06)$. There was no statistically significant difference between the third and other groups ( $p=0,121$ to 0,999 ). 
Based on the above results, the authors proved their hypothesis that organizations which invested more in their employees training program achieved higher level of organizational productivity and service quality.

Table 6 Tests of between-subjects effects

\begin{tabular}{|c|c|c|c|c|c|c|c|c|}
\hline Source & $\begin{array}{l}\text { Dependent } \\
\text { Variable }\end{array}$ & $\begin{array}{l}\text { Type III Sum } \\
\text { of Squares }\end{array}$ & $\mathrm{d} f$ & $F$ & Sig. ${ }^{\mathrm{d}}$ & Partial Eta Squared & Noncent. Parameter & Observed Power ${ }^{\mathrm{C}}$ \\
\hline \multirow[t]{2}{*}{ Corrected Model } & Productivity & $19,943^{\mathrm{a}}$ & 8 & 4,174 & 0,000 & 0,185 & 33,390 & 0,993 \\
\hline & Servqual & $15,943^{\mathrm{b}}$ & 8 & 3,509 & 0,001 & 0,160 & 28,070 & 0,977 \\
\hline \multirow[t]{2}{*}{ Intercept } & Productivity & 1304,389 & 1 & 2183,88 & 0,000 & 0,937 & 2183,882 & 1,000 \\
\hline & Servqual & 1505,538 & 1 & 2650,69 & 0,000 & 0,947 & 2650,695 & 1,000 \\
\hline \multirow[t]{2}{*}{$\mathrm{TC}$} & Productivity & 6,885 & 2 & 5,763 & 0,004 & $\mathbf{0 , 0 7 3}$ & 11,527 & 0,862 \\
\hline & Servqual & 6,025 & 2 & 5,304 & 0,006 & 0,067 & 10,608 & 0,831 \\
\hline \multirow[t]{2}{*}{ TD } & Productivity & 4,508 & 2 & 3,774 & 0,025 & 0,049 & 7,547 & 0,681 \\
\hline & Servqual & 3,724 & 2 & 3,278 & 0,040 & 0,043 & 6,557 & 0,615 \\
\hline \multirow[t]{2}{*}{$\mathrm{TC} \times \mathrm{TD}$} & Productivity & 10,946 & 4 & 4,581 & 0,002 & $\mathbf{0 , 1 1 1}$ & 18,326 & 0,940 \\
\hline & Servqual & 6,550 & 4 & 2,883 & $\mathbf{0 , 0 2 5}$ & $\mathbf{0 , 0 7 3}$ & $\mathbf{1 1 , 5 3 2}$ & 0,769 \\
\hline \multirow[t]{2}{*}{ Error } & Productivity & 87,800 & 147 & & & & & \\
\hline & Servqual & 83,493 & 147 & & & & & \\
\hline \multirow[t]{2}{*}{ Total } & Productivity & 2118,000 & 156 & & & & & \\
\hline & Servqual & 2438,000 & 156 & & & & & \\
\hline \multirow[t]{2}{*}{ Corrected Total } & Productivity & 107,744 & 155 & & & & & \\
\hline & Servqual & 99,436 & 155 & & & & & \\
\hline \multicolumn{9}{|c|}{ a. $R$ Squared $=0,185($ Adjusted $R$ Squared $=0,141)$} \\
\hline \multicolumn{9}{|c|}{ b. $R$ Squared $=0,160$ (Adjusted $R$ Squared $=0,115$ ) } \\
\hline \multicolumn{9}{|c|}{ c. Computed using alpha $=0,05$} \\
\hline \multicolumn{9}{|c|}{ d. Bonferroni adjustment of alpha $=0,025$} \\
\hline
\end{tabular}

\begin{tabular}{|c|c|c|c|c|c|c|c|c|c|c|}
\hline Dependent Variable & TC $I$ & $\mathrm{TC} J$ & Mean Difference $I-J$ & $S E$ & Sig. & $\mathrm{TD} I$ & $\operatorname{TD} J$ & Mean Difference $I-J$ & $S E$ & Sig. \\
\hline \multirow{5}{*}{ Rating of level of productivity } & \multirow{2}{*}{1} & 2 & $-0,16$ & 0,16 & 0,965 & \multirow{2}{*}{1} & 2 & $-0,39^{*}$ & $\mathbf{0 , 1 3 8}$ & 0,016 \\
\hline & & 3 & $-0,45^{*}$ & 0,143 & 0,006 & & 3 & $-0,28$ & 0,176 & 0,322 \\
\hline & \multirow{2}{*}{2} & 1 & 0,16 & 0,16 & 0,965 & \multirow{2}{*}{2} & 1 & $\mathbf{0 , 3 9 *}$ & $\mathbf{0 , 1 3 8}$ & 0,016 \\
\hline & & 3 & $-0,29$ & 0,159 & 0,207 & & 3 & 0,1 & 0,184 & 1 \\
\hline & 3 & 1 & $0, \mathbf{4 5}^{*}$ & 0,143 & 0,006 & 3 & 1 & 0,28 & 0,176 & 0,322 \\
\hline \multirow{6}{*}{ Rating of service quality } & \multirow{2}{*}{1} & 2 & $-0,17$ & 0,156 & 0,873 & \multirow{2}{*}{1} & 2 & $-0,37^{*}$ & 0,134 & 0,019 \\
\hline & & 3 & $-0,46^{*}$ & $\mathbf{0 , 1 3 9}$ & $\mathbf{0 , 0 0 3}$ & & 3 & $-0,35$ & 0,171 & 0,121 \\
\hline & \multirow{2}{*}{2} & 1 & 0,17 & 0,156 & 0,873 & \multirow{2}{*}{2} & 1 & $0,37^{*}$ & 0,134 & $\mathbf{0 , 0 1 9}$ \\
\hline & & 3 & $-0,3$ & 0,156 & 0,172 & & 3 & 0,02 & 0,18 & 1 \\
\hline & \multirow{2}{*}{3} & 1 & $0,46^{*}$ & 0,139 & $\mathbf{0 , 0 0 3}$ & \multirow{2}{*}{3} & 1 & 0,35 & 0,171 & 0,121 \\
\hline & & 2 & 0,3 & 0,156 & 0,172 & & 2 & $-0,02$ & 0,18 & 1 \\
\hline \multicolumn{11}{|l|}{ Based on observed means. } \\
\hline \multicolumn{11}{|c|}{ The error term is Mean Square (Error) $=0,568$. } \\
\hline
\end{tabular}

\section{CONCLUSION}

The human factor is one of the fundamental and most important elements in the process of achieving competitive position of enterprise [37]. Many researchers around the world claim that companies can enhance their competitiveness by investing in their employees, as human potentials that are inevitably one of the key factors to sustain long-term success of organizations. Companies that provide broad-based training for their employees invest in the future, since those companies understand the needs of their employees, and they are trying to develop their business in the line with the development of their employees. This is important to bear in mind if it is known that the role of training has changed and that today training is seen as a way to enhance individual capabilities, team effectiveness and organizational competitive advantage.

The main aim of the research was to explore the effects of investment in employees' development, measured by number of training days and a percentage of operating costs invested in development and training, on the level of organizational productivity and service quality. In order to explore the proposed hypothesis the authors used two-way multivariate analysis of variance (MANOVA) on the data from 160 companies. Results of the correlation test showed that there are statistically significant correlations between dependent and independent variables. The level of training costs, as percentage of annual labour costs invested in training, is positively correlated with the level of productivity and service quality. A number of training days spent on training, as second important training determinant, is positively correlated to the productivity and level of service quality, too. Also, productivity and service quality are positively correlated. The most important results from the two-way MANOVA tests showed that there was a statistically significant interaction effect between training costs and number of training days on the combined dependent variables. Post hoc tests revealed that companies that invest more than $5 \%$ of their labour costs in training at annual level will have higher level of productivity compared with companies that invest less than $2 \%$. Companies that invest less than 5 days on training will have lower level of productivity compared with companies that invest from 5 to 10 days. Service quality was statistically significantly lower if organizations spent less than 5 days compared to the companies that spent 5 to 10 days for training. The authors proved their hypothesis $\mathrm{H} 1$ that organizations which invest more in their employees 
training program achieve higher level of organizational productivity and service quality.

The present results are in the line with previous studies, especially if we take into account the region. According to Slavić and Berber [38], and Nikandrou et al. [39] number of days spent on employees' training is positively related to organizational success measured by productivity and service quality. Cvjetković et al. and Morley et al. also proved that employees' training was crucial in achieving higher level of organizational performances $[27,10]$. Organizations that invested more in training showed higher level of productivity and service quality, but also profitability and even rate of innovation. Results of the research are very important for the theory of HRM in general, but especially for the HRM practice in organizations. Implications lie in the fact that the research proved positive relations between training and productivity and service quality. CEOs, line managers, HR managers and team leaders should be aware of the possibilities that are related to the training and its influence on better performances of employees. Training assumes investments, which are tracked as costs in financial statements, but those amounts should not be understood only as a cost, but also as a possibility to reach more in the future.

\section{REFERENCES}

[1] Sparrow, P., Hird, M., Hesketh, A., \& Cooper, C. (Eds.) (2010). Leading HR. Basingstoke. UK: PalgraveMacmillan. https://doi.org/10.1057/9780230281349

[2] Poór, J., Slavić, A., \& Berber, N. (2017). The challenges of HRM activities at MNC subsidiaries in CEE region: Based on CEEIRT 2015/16 research. Anali Ekonomskog fakulteta u Subotici, 53(38), 109-120. https://scindeks.ceon.rs/ article.aspx?artid=0350-21201738109P

[3] Boxall, P. \& Purcell, J. (2016). Strategy and Human Resource Management. UK: Palgrave Macmillan. https://doi.org/10.1007/978-1-137-40765-8

[4] Huselid, M. A. (1995). The impact of human resource management practices on turnover, productivity, and corporate financial performance. Academy of Management Journal, 38(3), 635-672. https://doi.org/10.5465/256741

[5] Aguinis, H. \& Kraiger, K. (2009). Benefits of training and development for individuals and teams, organizations, and society. Annual Review of Psychology, 60, 451-474. https://doi.org/10.1146/annurev.psych.60.110707.163505

[6] Katić, I., Ivanišević, A., Grubić-Nešić, L., \& Penezić, N. (2018). Effects of Sociodemographic Characteristics and Personality Traits on Career Development. International Journal of Aging and Human Development, 87(2), 201-216. https://doi.org/10.1177\%2F0091415017743008

[7] Saridakis, G., Lai, Y., \& Cooper, C. L. (2017). Exploring the relationship between HRM and firm performance: A metaanalysis of longitudinal studies. Human Resource Management Review, 27(1), 87-96. https://doi.org/10.1016/j.hrmr.2016.09.005

[8] Hansson, B. (2007). Company-based determinants of training and the impact of training on company performance: Results from an international HRM survey. Personnel Review, 36(2), 311-331. https://doi.org/10.1108/00483480710726163

[9] McNamara, T. K., Parry, E., Lee, J., \& Pitt-Catsouphes, M. (2012). The effect of training on organizational performance: differences by age composition and cultural context. The International Journal of Human Resource Management, 23(6), 1226-1244. https://doi.org/10.1080/09585192.2011.561253

[10] Morley, M. J., Slavic, A., Poór, J., \& Berber, N. (2016). Training practices and organisational performance: A comparative analysis of domestic and international market oriented Organisations in Central \& Eastern Europe. Journalfor East European Management Studies, 21(4), 406432. https://doi.org/10.5771/0949-6181-2016-4-406

[11] Ralević, P. V., Dragojlović, A., Dobrodolac, M., Denić, N. M., \& Nešić, Z. (2015). Increasing organizational performance by human resource management. Tehnički vjesnik, 22(2), 263-269. https://doi.org/10.17559/TV-20130905124436

[12] Riley, S. M., Michael, S. C., \& Mahoney, J. T. (2017). Human capitalmatters: Market valuationoffirminvestments in trainingandthe role ofcomplementaryassets. Strategic Management Journal, 38(9), 1895-1914. https://doi.org/10.1002/smj.2631

[13] Salas, E., Tannenbaum, S. I., Kraiger, K., \& Smith-Jentsch, K. A. (2012). Thescienceoftraininganddevelopment in organizations: whatmatters in practice. Psychological Science in the Public Interest, 13(2), 74-101. https://doi.org/10.1177/1529100612436661

[14] Byars, L. L. \& Rue L. W. (2004). Human Resource Management, $7^{\text {th }}$ Edition. Boston: McGraw-Hill.

[15] Héder, M., Szabó, S., \& Dajnoki, K. (2018). Effect of labour market changes on HR functions. Anali Ekonomskog fakulteta u Subotici, (39), 123-138. https://doi.org/10.5937/AnEkSub1839123H

[16] Katić, I., Knežević, T., Berber, N., Ivanišević, A., \& Leber, M. (2019). The Impact of Stress on Life, Working, and Management Styles: How to Make an Organization Healthier? Sustainability, 11(15), 4026. https://doi.org/10.3390/su11154026

[17] Leber, M., Bastič, M., Moody, L., \& Krajnc, M. S. (2018). A study of the impact of ergonomically designed workplaces on employee productivity. Advances in Production Engineering \& Management, 13(1), 107-117. https://doi.org/10.14743/apem2018.1.277

[18] Ivanišević, A., Katić, I., Buchmeister, B., \& Leber, M. (2016). Business plan feedback for cost effective business processes. Advances in Production Engineering \& Management, 11(3), 173-182. https://doi.org/10.14743/apem2016.3.218

[19] Poor, J., ŠtanglŠušnjar, G., Slavić, A., \& Karoliny, Zs. (2012). Training practice in Central and Eastern European companies based on Cranet research. In C.B. Illes (Ed.). SMEs' Management in the 21st Century: Challenges and Solutions (pp. 271-283). Czestochowa: University of Technology, Facultyof Management. https://doi.org/10.18515/dBEM.M2012.n01.ch21

[20] Noe, R. A., Clarke, A. D., \& Klein, H. J. (2014). Learning in the twenty-first-century workplace. Annual Review of Organizational Psychology and Organizational Behavior, 1(1), 245-275. https://doi.org/10.1146/annurev-orgpsych-031413-091321

[21] Bell, B. S., Tannenbaum, S. I., Ford, J. K., Noe, R. A., \& Kraiger, K. (2017). 100 years of training and development research: What we know and where we should go. Journal of Applied Psychology, 102(3), 305-323. https://doi.org/10.1037/apl0000142

[22] Berber, N. \& Lekovic, B. (2018). The impact of HR development on innovative performances in central and eastern European countries. Employee Relations, 40(5), 762786. https://doi.org/10.1108/ER-08-2017-0188

[23] Stuken, T. \& Burtseva, O. (2017). Internal training of personnel in Russia and Belarus: The content and effectiveness. Strategic Management, 22(2), 9-17. https://scindeks.ceon.rs/article. aspx?artid=182134481702009S 
[24] De Grip, A. \& Sauermann, J. (2013). The effect of training on productivity: The transfer of on-the-job training from the perspective of economics. Educational Research Review, 8, 28-36. https://doi.org/10.1016/j.edurev.2012.05.005

[25] Saravani, S. R. \& Abbasi, B. (2013). Investigating the influence of job rotation on performance by considering skill variation and job satisfaction of bank employees. Tehnički vjesnik, 20(3), 473-478.

[26] Dearden, L., Reed, H., \& Van Reenen, J. (2006). The impact of training on productivity and wages: Evidence from British panel data. Oxford Bulletin of Economics and Statistics, 68(4), 397-421. https://doi.org/10.1111/j.1468-0084.2006.00170.x

[27] Cvjetković, M., Djordjević, D., \& Ćoćkalo, D. (2017). Influence of knowledge and quality on business performance of companies in Serbia. Tehnički vjesnik, 24(3), 847-853. https://doi.org/10.17559/TV-20160114211519

[28] Kyoon Yoo, D. \& Ah Park, J. (2007). Perceived service quality: Analyzing relationships among employees, customers, and financial performance. International Journal of Quality \& Reliability Management, 24(9), 908-926. https://doi.org/10.1108/02656710710826180

[29] Van Iddekinge, C. H., Ferris, G. R., Perrewé, P. L., Perryman, A. A., Blass, F. R., \& Heetderks, T. D. (2009). Effects of selection and training on unit-level performance over time: A latent growth modeling approach. Journal of Applied Psychology, 94, 829-843. https://doi.org/10.1037/a0014453

[30] Dhar, R. L. (2015). Service quality and the training of employees: The mediating role of organizational commitment. Tourism Management, 46, 419-430. https://doi.org/10.1016/j.tourman.2014.08.001

[31] Arroyo-López, P. E., Cárcamo-Solís, M. D. L., ÁlvarezCastañón, L., \& Guzmán-López, A. (2017). Impact of training on improving service quality in small provincial restaurants. Journal of Food service Business Research, 20(1), 1-14. https://doi.org/10.1080/15378020.2016.1192881

[32] Aragón-Sánchez, A., Barba-Aragón, I., \& Sanz-Valle, R. (2003). Effects of training on business results. The International Journal of Human Resource Management, 14(6), 956-980. https://doi.org/10.1080/0958519032000106164

[33] Zumrah, A. R. (2015). How to enhance the impact of training on service quality? Evidence from Malaysian public sector context. Journal of Workplace Learning, 27(7), 514-529. https://doi.org/10.1108/JWL-06-2014-0048

[34] Berber, N. \& Slavić, A. (2016). The Practice of Employees' Training in Serbia based on Cranet Research. Economic Themes, 54(4), 535-548. https://doi.org/10.1515/ethemes-2016-0027

[35] Leber, M., Ivanišević, A., Borocki, J., Radišić, M., \& Ślusarczyk, B. (2018). Fostering Alliances with Customers for the Sustainable Product Creation. Sustainability, 10(9), 3204. https://doi.org/10.3390/su10093204

[36] Chutima, P. \& Suchanun, T. (2019). Productivity improvement with parallel adjacent U-shaped assembly lines. Advances in Production Engineering \& Management, 14(1), 51-64. https://doi.org/10.14743/apem2019.1.311

[37] Duspara, L., Požega, Ž., \& Crnković, B. (2017). The influence of the human factor on competitiveness of enterprises in the metal processing industry in Croatia. Tehnički vjesnik, 24(2), 579-584 https://doi.org/10.17559/TV-20160715121934

[38] Slavić, A. \& Berber, N. (2019). The Role of Training Practice in Improving Organizational Performance in Selected Countries of the Danube Region. Engineering Economics, 30(1), 81-93. https://doi.org/10.5755/j01.ee.30.1.17857

[39] Nikandrou, I., Apospori, E., Panayotopoulou, L., Stavrou, E. T., \& Papalexandris, N. (2008). Training and firm performance in Europe: the impact of national and organizational characteristics. The International Journal of Human Resource Management, 19(11), 2057-2078. https://doi.org/10.1080/09585190802404304

\section{Contact information:}

\section{Ivana KATIĆ,}

University of Novi Sad, Faculty of Technical Sciences,

Trg Dositeja Obradovića 6, 21101 Novi Sad, Serbia

E-mail: ivana.katic@uns.ac.rs

\section{Nemanja BERBER,}

University of Novi Sad, Faculty of Economics,

Segedinski put No. 9-11, 24000 Subotica, Serbia

E-mail: berber@ef.uns.ac.rs

\section{Agneš SLAVIĆ,}

University of Novi Sad, Faculty of Economics,

Segedinski put No. 9-11, 24000 Subotica, Serbia

E-mail: slavica@ef.uns.ac.rs

\section{Andrea IVANIŠEVIĆ}

(Corresponding author)

University of Novi Sad, Faculty of Technical Sciences

Trg Dositeja Obradovića 6, 21101 Novi Sad, Serbia

E-mail: andreai@uns.ac.rs 